\title{
Editorial
}

\section{Early History of Cadaver Dissection}

"Anatomy is the foundation of medicine." The classical Greek physician Hippocrates declared, "and should be based on the form of the human body." ${ }^{1}$ The history of cadaver dissection (practical anatomy) as a science extends from the earliest examinations of sacrificial victims to the sophisticated analyses of the body performed by modern scientists. ${ }^{2}$ If we wish to see the startingpoint of systematic cadaver dissection we must go back to ancient times.

It is in Alexandria (Egypt), $3^{\text {rd }}$ century BC that we meet with the first human anatomists, Herophilus and Erasistratus. They not only dissected the dead human body, but even the living, in order to search for the hidden springs of life itself. ${ }^{3}$

It is curious to note how this belief that anatomists were addicted to ante-mortem dissection has not been peculiar to Egypt, but has pervaded all lands and all times. ${ }^{3}$ Vesalius was shipwrecked and died, when fleeing for his life on a similar charge. After his name became known around the world he was appointed as a court physician in Spain. By dissecting the body of a Spanish nobleman who had died in his care, Vesalius found, when he opened the man's chest, the heart was still beating. He was accused of murder and was brought before the Inquisition. The King commuted Vesalius's death. ${ }^{4}$ The Edinburgh act of 1505, giving the surgeons the body of one criminal annually "to make an anatomie of," was guarded by the proviso, "after he be died,"3

In the $2^{\text {nd }}$ century AD Claudias Galen compelled to go from Pergamus to Alexandria in order to see a skeleton. Even in Rome itself, and as court physician at a later period, Galen could dissect nothing but the lower animals. The burning of the dead by the Romans prohibited totally any attempt at anatomy, and instead of sending his students to Egypt to study anatomy, he sent them to Germany to dissect the slain among the national enemies, while he contented himself with the ape. This feeble light at Rome and Alexandria, however, was soon extinguished, and human dissection disappears from history for twelve centuries. ${ }^{3}$

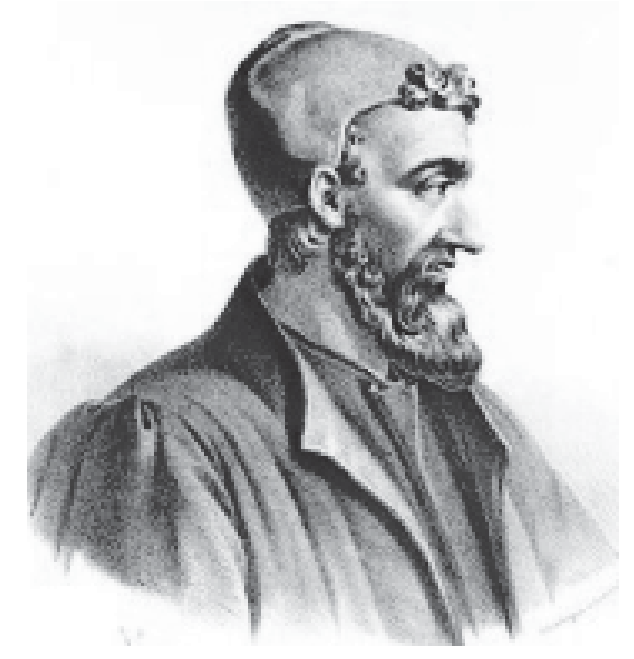

Fig.-1: Claudius Galen (120-200 B.C.) [From http://wastciv2.umwblogs.org].

Despite Galen's improvements on earlier anatomical studies and his other achievements, he is often remembered for the fact that the Catholic church did not allow his ideas to be criticized; thus many of his erroneous ideas were perpetuated and major progress in the field of anatomy was halted until the sixteenth century. By the end of the thirteenth century, the demand for accurate information was so great that the medical dissection of human corpses began in earnest. ${ }^{5}$

With the rise of the Italian universities came the first gleams of light. Bologna, the oldest of them all, is in many respects the most famous. Founded in 1119 as a school of Roman law, the fame of her professors was such that, as early as 1262 , no less than ten thousand students were gathered there. Here, two centuries before Vesalius was born, the first dissections of modern times were made. In 1315 , Mondini, or Mundinus, publicly dissected two female bodies, and established what was intended 
to be an annual custom, but which, strange to say, was soon neglected. ${ }^{3}$

The first illustration of a dissection was found in Fasiciculus Medicinae by Johannes de Ketham in 1491 and was inspired by the work of Mondino. Note the gentleman sitting in the chair overseeing the dissection; this is believed to be the origin of the term "chairman of the department". 6

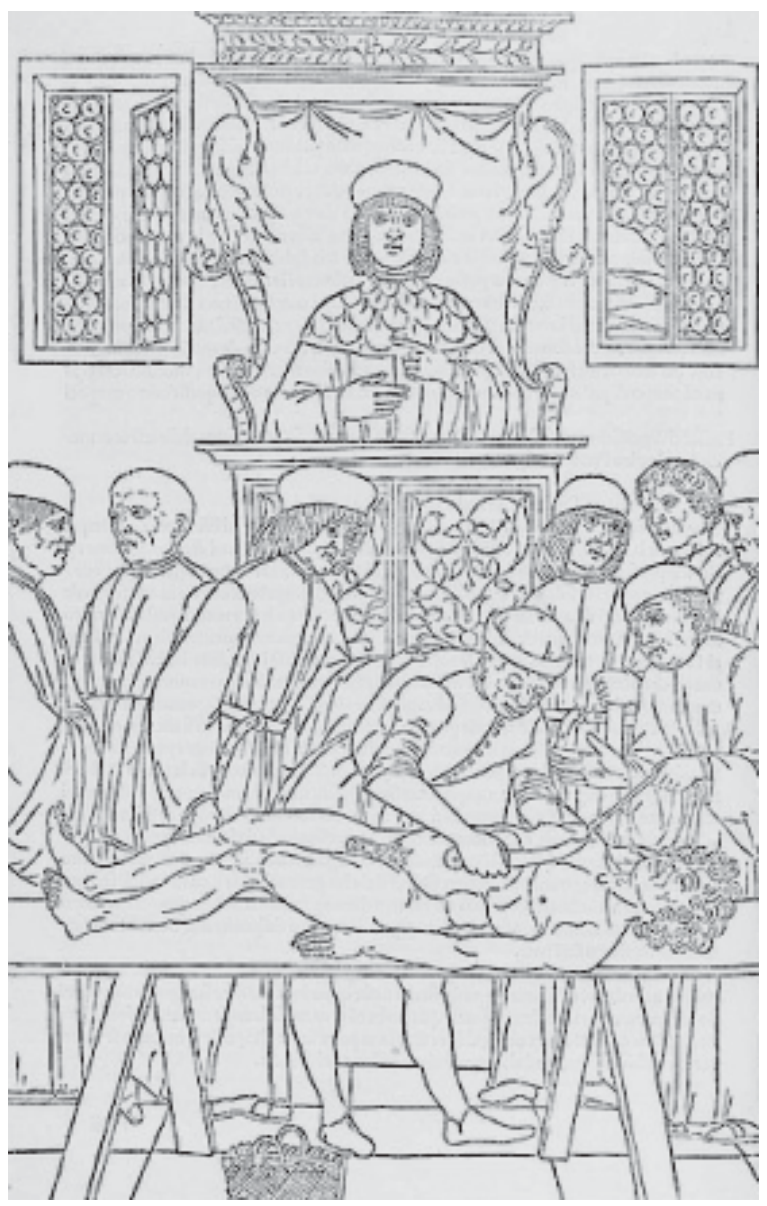

Fig.-2: Johannes de Ketham: Dissection scene from Fasiculo de Medicina (Venice, 1491) [From http://collectmedicalantiques.com].

From Mondini to Vesalius, the best anatomist of his age was undoubtedly Leonardo da Vinci, the great artist. Not only did he dissect the horse and other inferior animals, but also the human body. ${ }^{7}$ Over twenty-five years he dissects about thirty human corpses, many of them at a mortuary in Rome - until in 1515 the pope, orders him to stop. From these dissections he made his celebrated
Sketch-book of drawings in red chalk, now in the British royal collection. ${ }^{3}$

Galen's anatomy of the ape reigned supreme till the time of Vesalius. Anatomists at this time were still conditioned to revere the outdated notions of Aristotle and Galen, and if an autopsy revealed a deviation from prior teachings, the anatomists concluded that the body was abnormal. ${ }^{7}$

Vesalius took the lead with his monumental work De Humani Corporis Fabrica (The Structure of the Human Body) in 1543, now considered one of the greatest books in the history of medicine. The illustration on the title page of Vesalius's work is a dramatic proclamation about the new way of teaching and demonstrating anatomy that Vesalius thought he was introducing. In contrast to medieval representations of anatomy demonstrations, Vesalius has descended from the professorial chair and is actively engaged in the demonstration. ${ }^{8}$

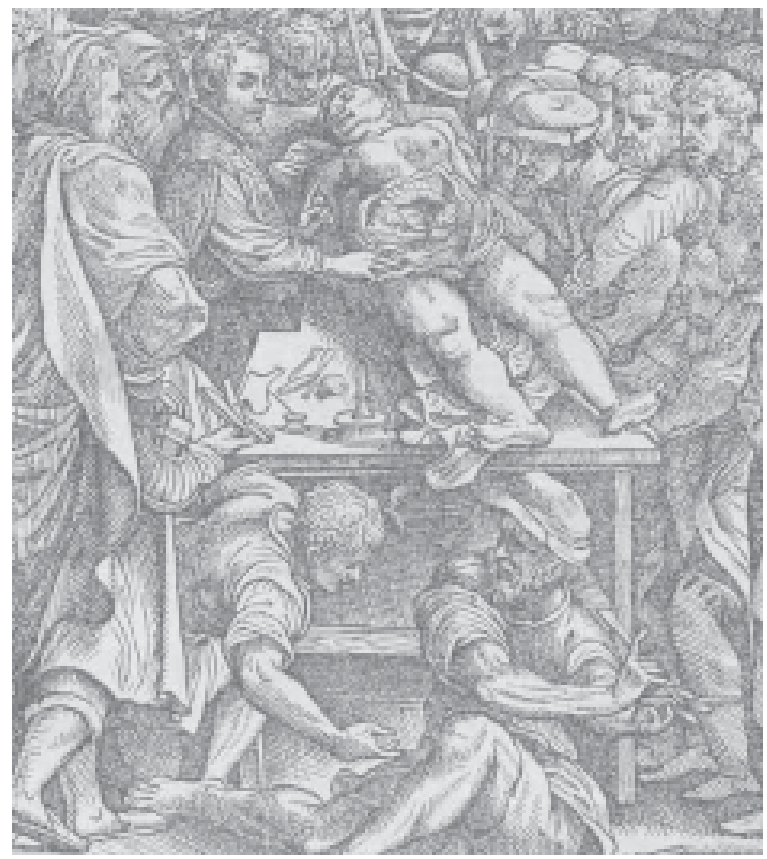

Fig.-3: Illustration from the title page of Vesalius's monumental work, De humani corporis fabrica libri septem, 1543 [From http://collectmedicalantiques. com].

Edinburgh act of 1505, which allowed of the annual dissection of a criminal, and also the early experience of the first Monro, which shows how 
rarely this was made available. In England, soon after the founding of the College of Surgeons in 1540, Henry VIII granted to the College of Surgeons the privilege of dissecting four executed prisoners annually, and in 1564, Elizabeth gave the same privilege to the College of Physicians. In 1581 the latter college created the lectureship on anatomy. Here, in 1615, Harvey was elected lecturer in anatomy, and gave his first public demonstrations of the circulation of the blood about a year later. ${ }^{3}$ Harvey dissected his own freshly dead family members (his father and sister) before burial. ${ }^{9}$

The facilities for general medical dissection, however, were very limited. Beyond the lecture-room no dissecting-rooms existed. Students saw the demonstration, and that was all. None of them dissected for themselves. The first Monro says that in his student days, early in the last century, his anatomy was limited "to seeing the dissection of the human body once in two or three years." To discourage it still further, in 1745 a fine of $£ 10$ was imposed on any one dissecting outside of BarberSurgeons' Hall. But such a state of affairs could not long exist. The profession, under the lead of William Hunter, soon broke away from such bonds, and for over half a century almost every distinguished anatomist had dissecting-rooms attached to his private dwelling, where he and his pupils cultivated the science. ${ }^{3}$

The infamous Burke and Hare murders were serial murders perpetrated in Edinburgh, Scotland, from November 1827 to 31 October 1828. The killings were attributed to Irish immigrants William Burke and William Hare, who sold the corpses of their 17 victims to provide material for dissection. Their purchaser was Doctor Robert Knox, a private anatomy lecturer. From their infamous method of killing their victims has come the word "burking", meaning to purposefully smother and compress the chest of a victim. ${ }^{12}$ Hare owned a boarding house; he occasionally killed a border who was late on rent. He did it by pressing pillow to man's face while Burke lay his body weight on top of victim. Burke was executed Jan. 28, 1829, and, by order of the judge, was publicly dissected. His skeleton is in the Anatomical Museum of the University of

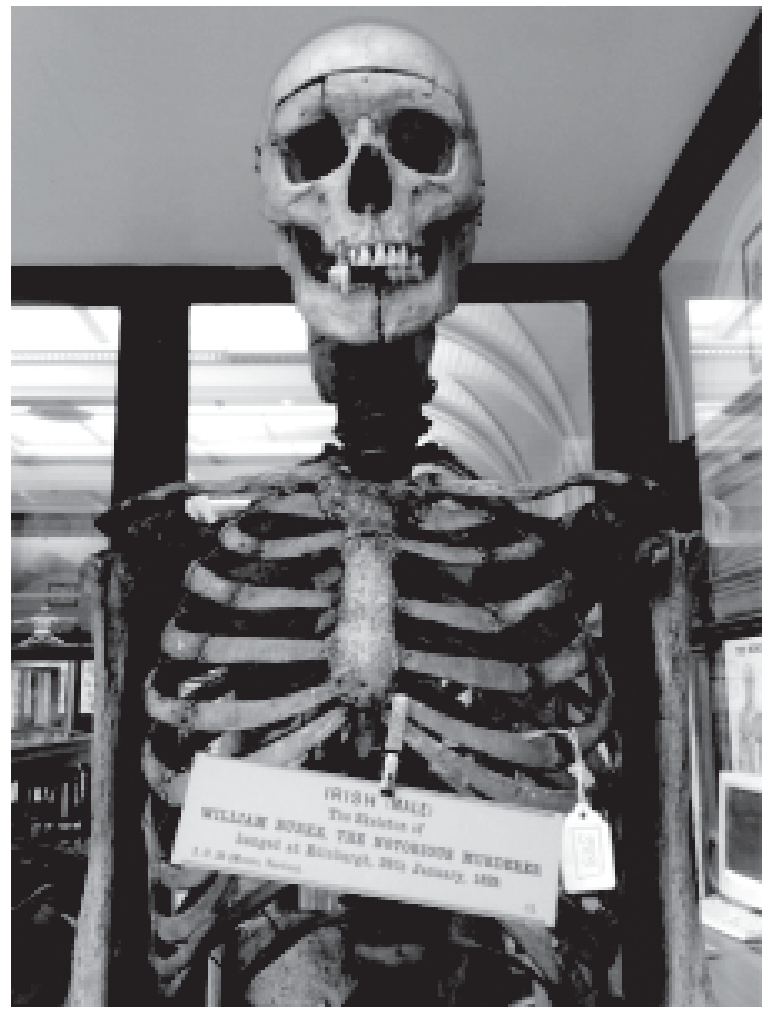

Fig.-4: Skeleton of William Burke, Anatomical Museum of the University of Edinburgh. [From http:/ /frogstorm.com].

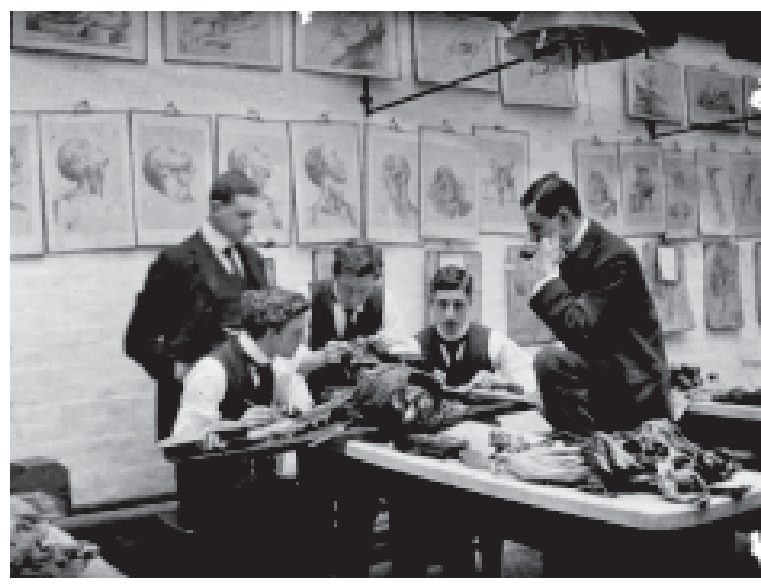

Fig.-5: Student dissecting a cadaver, 1898 [From http://www.sciencemuseum.org.uk].

Edinburgh. ${ }^{3}$ The Burke and Hare murders are referenced in Robert Louis Stevenson's short story, "The Body Snatcher". ${ }^{12}$ 
Such crimes called public attention to the imperative necessity of a proper source of supply for dissecting material. The Warburton anatomy bill accordingly was enacted August 1, 1832, giving all unclaimed bodies, under proper regulations, to the various schools. This has been the model for all subsequent acts. For several years there were loud complaints as to its operation, but experience gradually removed its difficulties. It is operated under this same concept until recently. ${ }^{3}$

\section{Dr. Md Mesbah Uddin}

Assistant Professor, Department of Anatomy, Kumudini Women's Medical College, Tangail.

\section{References:}

1. Sharp H. A brief essay on anatomical drawing.http://www.hsl.virginia.edu/historical/ anatomical/briefessay.html. [accessed on 26.05.2010]

2. Wikipedia article on history of anatomy. http:/ /en.wikipedia.org/ wiki/History_of_anatomy. [accessed on 26.05.2010]

3. Keen WW. A sketch of the early history of practical anatomy. Philadelphia: J.B. Lippincott \& Co: 1874.
4. Hajdu SI. A note from history: persecution of noted physicians and medical scientists. uww.annclinlabi.org. [accessed on 27.05.2010]

5. History of anatomy. http:// www. historyworld.net /wrldhis/PlainText Histories.asp. [accessed on 20.05.2010]

6. Collect medical antiques: anatomy. http:// www.collectmedicalantiques.com/ anatomy.html.[accessed on 20.05.2010]

7. Persaud TVN. Human anatomy: early history.http://www.umanitoba.ca/ libraries/ health/re/humananatomyhistory.html. [accessed on 20.05.2010]

8. Anatomical Illustrations in the Renaissance.http://honors.nmsu.edu/ weamon/ 304_anatomy.html. [accessed on 21.05.2010]

9. Who named it? http://www.whonamedit.com. [accessed on 25.05.2010]

10. Body snatchers: A history of the resurrectionists. http://www.capricornbooks. $\mathrm{ca} / \mathrm{si} / 23003 . \mathrm{html}$. [accessed on 22.05.2010]

11. Wikipedia article on Burke \& Hare murders.http://en.wikipedia.org/wiki/ Burke_and_Hare_murders. [accessed on 26.05.2010]. 